\title{
COMMUNICATION
}

\author{
[Comunicação]
}

\section{Selenium in bovine plasma, soil and forage measured by neutron activation analysis}

\author{
[Medição dos níveis de selênio no plasma bovino, solo e forragem por meio de \\ análises de ativação neutrônica] \\ S. Gil ${ }^{1,2}$, S. Hevia ${ }^{1}$, M. Dallorso ${ }^{3 *}$, S. Resnizky ${ }^{1}$ \\ ${ }^{1}$ Centro Atómico Ezeiza, Comisión Nacional de Energía Atómica. \\ ${ }^{2}$ Facultad de Ciencias Veterinarias, Universidad de Buenos Aires. \\ ${ }^{3}$ Facultad de Ciencias Agrarias, Universidad Nacional de Lomas de Zamora. \\ Ruta 4, Km 2 (1836) Llavallol, Buenos Aires, Argentina.
}

Beef cattle grazing on low lands of Buenos Aires province, in Argentina, are commonly affected by nutritional diseases (mineral imbalances, plant intoxication etc.; Culot, 1967). Low glutathione peroxidase activity in the blood of beef cattle grazing on certain parts of the Flooding Pampa area had been already informed (Duffy et al., 1986; Ruksan, 1998). Recently, low selenium plasma levels have been determined by neutron activation analysis (NAA) in a Solanum glaucophyllum intoxicated herd of the same area (Gil et al., 1999).

The present study used the NAA as a very sensitive technique to determine simultaneously soil, forage and plasma levels of selenium. The work was conducted in a breeding farm located at "Nueve de Julio" district, Buenos Aires, Argentina, on Spring 1999. Sixty animals (first parturition, mean body weight $380 \mathrm{~kg}$ ) were maintained grazing on native grass and supplemented with grass-legume pasture hay from August to October (6.5 kg DM/ animal), and wheat straw hay from September to October (1.5 kg DM/ animal). Six cows were chosen at random to determine selenium plasma levels. Blood samples were taken with heparinized syringes and plasma kept frozen until analysis. Two to $4 \mathrm{ml}$ plasma aliquots were lyophilized during 24 hours. Portions of 100-150mg of lyophilized plasma were taken and, irradiation, radiochemical separation and measurement were done as was detailed previously (Resnizky et al., 1999). Selenium plasma concentration of the sample was analyzed by one sample $\mathrm{T}$ test to compare with normal values. Soils under study are comprised under the categories typical natracualf and typical natralboles, being hydromorphic and moderately alkaline (Mapa...,1989). Three different fractions of the grazing field were sampled for soil and fresh forage: up land, half slope land and low land, each one occupying a relative surface of 13,70 and $17 \%$ of total area (56ha), respectively. The slope along the three fractions was $0.6 \%$. Samples of soil taken from horizon A1 were pooled within each fraction, dried at room temperature (DM), sieved through a $750 \mu \mathrm{m}$ mesh and weighed to be analyzed by Instrumental NAA. Samples were irradiated at RA-3 reactor with an approximate thermal neutron flux of $3 \times 10^{13} \mathrm{~cm}^{-1} \mathrm{~s}^{-2}$ for six hours. After 30 days the total selenium was determined through its long-lived nuclide ${ }^{75} \mathrm{Se}$ by gamma-ray spectrometry, using coal fly ash (SRM) NIST $1633 \mathrm{~b}$ as standard reference material. Fresh forage samples were cut with scissors, almost completely inside at random selected areas, conditioned into plastic bags and weighed immediately (fresh weight) and after a week in

Recebido para publicação em 6 de março de 2003

Recebido para publicação, após modificações, em 29 de setembro de 2003

*Corresponding author

e-mail: dollorso@agrarias.net 
electric oven at $<100^{\circ} \mathrm{C}$ (dry weight), to determine dry matter proportion (DM\%). The samples were pooled within each fraction, washed with distilled water and dried again before grinding and sieving through a $750 \mu \mathrm{m}$ mesh to be analyzed by NAA. Samples of wheat straw hay and pasture hay, were taken directly from the place where cows went to eat every day and treated as fresh forage samples to analyze their selenium content (Resnizky et al., 1999).

Mean plasma selenium was below normal: $30.1 \pm 4.6 \mathrm{ng} / \mathrm{ml} \quad(\mathrm{P} \leq 0.05 ; \mathrm{n}=6)$. According Mallison et al. (1985), normal mean is equal to $50 \mathrm{ng} / \mathrm{ml}$. Selenium content and standard deviation of the assay of soil samples obtained in upland, half slope land and low land fractions were $3.4 \pm 0.1 ; \quad 3.5 \pm 0.3$ and $3.9 \pm 0.04 \mu \mathrm{g} / \mathrm{g}$, respectively. Published data have informed soil profiles ranging from 0.02 to $2.5 \mu \mathrm{g} / \mathrm{g}$ (Shanberger, 1983b). Selenium content and standard deviation of the assay of fresh forage samples obtained in upland, half slope land and low land fractions were $0.13 \pm 0.04 ; 0.19 \pm 0.06$ and $<0.04 \mu \mathrm{g} / \mathrm{g}$, respectively. Selenium level in wheat straw hay was $<0.04 \mathrm{ug} / \mathrm{g}$, while pasture hay contained $0.21 \pm 0.07 \mathrm{ug} / \mathrm{g}$ of this mineral. Selenium-responsive diseases in grazing animals have been associated with forages with selenium being less than 0.05ppm (Shanberger, 1983a).

The results of the present study confirm previous data showing low selenium plasma levels in cows of Flooding Pampa Area. The low selenium content of fresh forage from low land fractions of the field and of wheat straw hay could account for animal selenium status. Total selenium content of soil samples did not explain the selenium deficiency observed in cows. Future work to elucidate the mechanisms leading the animals to the deficiency might include more complete chemical analysis of soil.

Key words: selenium, deficiency, cows, neutron activation analysis.

\section{RESUMO}

A deficiência de selênio já foi identificada pela medição da atividade da enzima glutationa de peroxidase no sangue de animais (vacas) criados em certas regiões do Pampa Úmido, mais especificamente na cidade de Nueve de Julio (Buenos Aires - Argentina). Em trabalho anterior, a análise de ativação neutrônica confirmou esses baixos níveis de selênio em uma determinada fazenda de cria para gado de corte. Neste trabalho, foram analisados os niveis de selênio no solo, na forragem e no plasma dos animais do mesmo estabelecimento. A população analisada $(n=60)$ apresentou níveis de selênio abaixo do normal $(30,1 \pm 4,6 \mu \mathrm{g} / \mathrm{ml})$. De maneira semelhante, a concentração de selênio da forragem consumida - matéria seca igual a 30\% - proveniente de uma área de baixada do piquete, assim como o feno de palha de trigo $(M S=91 \%)$ utilizado como suplemento, foi muito baixa $(<0,05 \mu g / g M S)$. A concentração de selênio no solo foi maior (entre 3,4 e 3,9 $\mu \mathrm{g} / \mathrm{g} M S$ ) do que o intervalo normal (entre 0,02 e 2,50 $\mu \mathrm{g} / \mathrm{g} \mathrm{MS}$ ) em todas as frações analisadas. Desse modo, confirma-se que a deficiência de selênio nos animais analisados é atribuída por uma determinação direta do mineral, ou seja, os resultados indicam que pode existir relação entre a baixa concentração de selênio na forragem e no suplemento, e sua deficiência nos animais.

Palavras-chave: selênio, deficiência, análises por ativação neutrônica.

\section{REFERENCES}

CULOT, J. PH.; FERNÁNDEZ TUÑÓN, E.; BOLAÑO, A. et al. Condiciones edáficas e hidrológicas relacionadas con desequilibrios minerales del ganado vacuno de la zona de cría del sudoeste bonaerense. Bol. Tec., FAO-INTA, EEA Balcarce, v.53, p.3-12, 1967.
DUFFY, J.; MIQUET, J.; RUKSAN, B.E. et al. Enfermedad del músculo blanco en terneros de cría. Vet. Arg., III, no 21, p.16-22, 1986.

GIL, S.; PAWLAK, S.E.; HEVIA, S. et al. Niveles de selenio plasmático en un rodeo de cria afectado de Enteque Seco. CONGRESO DE MEDICINA VETERINÁRIA DE CONE SUL, 
3. Gramado, Rio Grande do Sul, Brasil, 25 al 29 de Octubre, 1999.

MALLINSON, C.; ALLEN, W.; SANSOM, B.. Barium selenate injections in cattle: effects on selenium concentrations in plasma and liver and residues at site of injection. Vet. Rec., v.117, p.405-407, 1985.

MAPA de suelos de la provincia de Buenos Aires. Escala 1:500.000, Secretaría de Agricultura, Ganadería y Pesca, Instituto Nacional de Tecnología Agropecuaria, p.227, 1989.

RESNIZKY, S.; DALLORSO, M.E.; PAWLAK, S. E. Neutron activation analysis of selenium in bovine plasma samples. Biol. Trace Elem. Res., v.71-72, p. 343-347, 1999.

RUKSAN, B.E. Deficiencia de selenio. REUNIÓN CIENTÍFICA TÉCNICA ASOCIACIÓN ARGENTINA DE VETERINARIOS DE LABORATORIOS DE DIAGNÓSTICO, 12., Mar del Plata, Argentina, Noviembre, 1998.

SHANBERGER, R.J. Selenium deficiency diseases in animals. In: BIOCHEMISTRY OF SELENIUM. New York: Plenum, 1983a. p.3158.

SHANBERGER, R.J. Environmental occurrence of selenium. In: BIOCHEMISTRY OF SELENIUM. New York: Plenum Press, 1983 b. p.167-183. 